\title{
MEASURES OF PATIENT EXPOSURE TO IONIZING RADIATION DURING INTERVENTIONAL RADIOLOGY PROCEDURES
}

\author{
Valentina Opancina ${ }^{1,2}$, Radisa Vojinovic ${ }^{1,2}$ \\ IUniversity of Kragujevac, Faculty of Medical Sciences, Department of Radiology, Kragujevac, Serbia \\ ${ }^{2}$ Clinical Center "Kragujevac", Department of Radiology, Kragujevac, Serbia

\section{MERE IZLOŽENOSTI PACIJENTA JONIZUJUĆEM ZRAČENJU TOKOM INTERVENTNIH RADIOLOŠKIH PROCEDURA}

\author{
Valentina Opančinal, ${ }^{1,2}$ Radiša Vojinovićl,2 \\ IUniverzitet u Kragujevcu, Srbija, Fakultet medicinskih nauka, Katedra za radiologiju, Kragujevac \\ ${ }^{2}$ Klinički centar , Kragujevac“, Služba za radiološku dijagnostiku, Kragujevac
}

\begin{abstract}
Procedures used in interventional radiology brought considerable prosperity to patients when compared to traditional surgery. The negative aspect of interventional radiology procedures are effects of ionizing radiation on patients and the medical team that performs these procedures. The amount of ionizing radiation is defined as exposure, which is expressed in different measures. In order to present the effects of radiation, different types of units are used, since it is not achievable to quantify the stochastic and deterministic effects directly. Dose-area product, air kerma and fluoroscopy time are units that are used in interventional radiology, all of them are granted by the angiography machine. These units are used for the estimation of the entrance-skin dose and effective dose, which are associated with deterministic and stochastic effects, respectively. Finally, the main purpose is to obtain the absorption dose, which helps us to observe the patient exposure during interventional radiology procedures. The aim of this paper is to describe measures of patient exposure to ionizing radiation during interventional radiology procedures, using a thorough literature search.
\end{abstract}

Key words: radiation, ionizing; radiation exposure; radiology, interventional; radiation dosage; patients

\section{INTRODUCTION}

Procedures used in interventional radiology (IR) brought considerable prosperity to patients when compared to traditional surgery (1). The negative aspect of interventional radiology procedures (IRP) are effects of ionizing radiation on patients and the medical team that performs these procedures (2). The amount of ionizing radiation is defined as exposure, which is expressed in different measures (2).

Radiation dose (RD) that is transferred to patient during IRP is used to quantify the risk of stochastic and deterministic effects (3). Radiation affects the organism by harming the DNA or producing free radicals $(4,5)$. Impairment of DNA can cause a mutation, but it does not interfere with the mythosis which can possibly contribute to stochastic effect, just as oncogenesis. Determinist effects are caused by broader destruction, such as cell necrosis and tissue injury, which happens after a certain

\section{SAŽETAK}

Procedure koje se koriste $u$ interventnoj radiologiji donele su značajnu korist pacijentima u poređenju s tradicionalnom hirurgijom. Negativni aspekt interventnih radioloških procedura su efekti jonizujuceg zračenja na pacijente $i$ medicinski tim koji ih obavlja. Količina jonizujucég zračenja definišse se kao izloženost, koja se izražava različitim merama. Da bi se prikazali efekti zračenja, koriste se različite vrste jedinica, jer nije moguce direktno kvantifikovati stohastičke $i$ determinističke efekte zračenja. Proizvod doze i površsine, kerma vazduha i vreme fluoroskopije jedinice su koje se koriste u interventnoj radiologiji, a sve ih prikazuje angiograf. Ove jedinice se koriste za procenu ulazne doze u kožu i efektivne doze, koje su povezane sa determinističkim i stohastičkim efektima. Najzad, glavna svrha je dobijanje doze apsorpcije, što nam pomaže da posmatramo izloženost pacijenta tokom interventnih radioloških procedura. Cilj ovog rada bio je da se opišu mere kojima se prikazuje izloženost pacijenta jonizujućem zračenju tokom interventnih radioloških procedura opširnom pretragom literature.

Ključne reči: zračenje, jonizujuće; izloženost zračenju; radiologija, interventna; doza zračenja; pacijenti

threshold of RD is crossed. For example, International Commission on Radiological Protection (ICRP) presented that the threshold for skin injury is between 2 Gy and 3 Gy, for lens is $500 \mathrm{mGy}$ and for heart it is also $500 \mathrm{mGy}$ $(6,7)$. Unlike deterministic effects, stochastic effects do not have a threshold, but are established on statistical probability that RD will lead to an effect (8).

In order to present the effects of radiation, different types of units are used, since it is not achievable to quantify the stochastic and deterministic effects directly. Dose-area product (DAP), air kerma (AK) and fluoroscopy time are units that are used in interventional radiology, all of them are granted by the angiography machine (9). These units are used for the estimation of the entrance-skin dose (ESD) and effective dose (ED), which are associated with deterministic and stochastic effects, respectively (10-12). Finally, the main purpose is to obtain the absorption dose (AD), which helps us to observe the patient exposure during IRP. This is necessary, especially 
for interventional radiologists who perform this type of procedures, in order to analyze the exposure of patients with the determined normative and to possibly reduce potential risk factors (13-15). Because of that, it is essential to educate radiologists, especially those who perform interventional procedures, about measures of radiation, in order to prevent or downsize possible stochastic and deterministic effects $(1,16)$.

The aim of this paper is to describe measures of patient exposure to ionizing radiation during interventional radiology procedures, using thorough literature search.

\section{MATERIALS AND METHODS}

A thorough exploration of the literature was performed, using the Medline and Ebsco databases and the subsequent terms: (radiation monitoring OR radiation dose OR radiation exposure OR radiation measure OR radiation unit $\mathrm{OR}$ radiation parameter) AND (interventional radiology OR interventional vascular procedure OR interventional non-vascular procedure OR interventional procedure OR interventional neuroradiology OR interventional cardiology) AND (patients). As a result of literature search, we singled out original research papers, meta-analyses and review papers, which were fully available and written in the English language. We also selected substantial reference lists of published papers which could help the readers to better comprehend the paper's substance.

\section{RADIATION PARAMETERS}

To this day, there is no direct approach for measurement of the skin dose and effective dose during IRP $(17,18)$. Still, there are other radiation parameters such as dose-area product, air kerma as well as fluoroscopy time, which are used to calculate entrance skin dose, as well as equivalent dose (1).

\section{Dose area product}

Dose area product is expressed in Gy- $\mathrm{cm}^{2}$, since it is the product of the air kerma, which is expressed in Gy or $\mathrm{mGy}$, and the exposed area, which is expressed in $\mathrm{cm} 2$, in cases of evenly exposed area (4). Dose-area product is a parameter that presents $\mathrm{RD}$, which is absorbed by air and multiplied by the cross-sectional area of the x-ray beam, found in the quantification spot (19). DAP may also be described as the integral of RD across the X-ray beam (20). Cumulative DAP is the sum of all products for all parts of an IRP (1). DAP can also be measured by the DAP meters, which use huge-area transmission ionization compartments, which are located in the space between the patient and shutters of the final collimator $(1,21)$. There is also a way to calculate DAP in real-time, employing an algorithm that uses framework of the X-ray generator, in combination with the collimator data (21).
DAP is significant, fast and trustworthy radiation parameter, since it provides the information on the patient $\mathrm{RD}$ and a risk of a stochastic effect $(1,22)$. In literature, DAP is called as "the integral of air kerma", because it quantifies the energy that the patient receives (23).

The great feature of DAP is that it can be converted by using various factors into estimated ED and PSD $(24,25)$. Nonetheless, the conversion factors are not standardized for all the IRP. PSD can be calculated using DAP, if the field of the skin that was exposed to the radiation is known (22). The skin dose can be also derived indirectly, by use of meter positioned in the X-ray tube outlet. However, due to the variance of the X-ray focus to skin distance, as well as the X-ray field range and also magnification of the image intensifier, this method is not widely used (22). The other way to measure the patients' dose is by using thermo-luminescent dosimeters or films which must be placed in the area of X-ray entrance in the body (26). It is an accurate method, but expensive and requires more time than DAP (22).

Previous studies have shown that there is a strong correlation between DAP and maximum skin dose (MSD) in all interventional cardiology procedures $(p<0.0001)$, except for percutaneous angioplasty performed in left coronary artery (27).

\section{Air kerma}

In order to fully understand the term air kerma, we need to know that kerma stands for ,kinetic energy released per unit mass" (of air). It demonstrates the amount of radiation energy that is expressed in joules $(\mathrm{J})$, really deposited in or absorbed in a unit mass $(\mathrm{kg})$ of air. Hence, the unit for AK is $\mathrm{J} / \mathrm{kg}$, likewise the radiation unit, the gray.

Air kerma is measured free-in-air, furthermore on the central axis of the X-ray beam and at a specific distance from the focus (28). Reference AK is concentrated at a certain spot in space (also called the "patient entrance reference point") relative to the fluoroscopy system gantry (23). For C-arm fluoroscopy systems, that spot is a point adjacent to the central beam of $\mathrm{x}$-ray, " $15 \mathrm{~cm}$ back from the isocenter approaching the focal spot" (29). Reference $\mathrm{AK}$ and DAP are constructed in order to get the better evaluation of the radiation injury risk (30). Furthermore, incident air kerma is measured on the position where it enters the patient or in some cases, phantom (23).

\section{Time of fluoroscopy}

Fluoroscopy time is third parameter, which is provided during interventional procedures, by angiography unit. It is measured in seconds (23). This unit is used for estimation of RD during all IRP (7). However, it does not correlate strongly with the exposure of patients during interventional procedures in radiology $(7,23)$. However, the Food and Drug Administration and ICRP suggest its observation (1). 


\section{PATIENT RADIATION DOSES}

\section{Entrance-skin dose}

The purpose of the skin dose is to discover the potential for the deterministic effect (8). It is estimated from DAP. Still, this estimation may not be completely accurate, due to the movement of X-ray tube around the patient (3). Exceeding a threshold, which is 2 Gy results in a short-term erythema, 24-48 hours after the procedure. In cases of higher skin dose, serious skin injuries happen (3, 24, 25).

Entrance skin dose is the dose which is absorbed in the patient skin at a certain site $(4,8)$. The total ESD (TESD) is calculated when the ESDs for all segments of an IRP are added, considering that the patient's MSD will be alike the TESD, if the angles and views used while performing IRP are constant, which happens rarely. Therefore, the MSD will not be the same as the TESD in these types of procedures. Typically, the TESD shows greater value than the MSD (1). To protect against patient skin injury during IRP, the MSD should be monitored in real-time (1).

Formerly, the skin dose monitor was used to measure ESD during IRP (31). This is no longer a case due to the toxicity, which is associated with its zinc-cadmium sensor. Two dimensional methods (such as X-ray film) are better than dot dosimeters, since they have the possibility to evaluate the dose distribution and MSD area (32). Several studies report the benefit of the MSD evaluation using Xray film during IRP, with a major downside due to the fact that the result wasn't available in real time. Others reported usage of "thermoluminescent dosimeter (TLD) vest" made of 3-cm-spaced pockets, which are used to insert TLDs for measuring skin doses directly (33). Nevertheless, these vests don't provide real-time data. The radiosensitive indicator is additionally used to obtain the two-dimensional doses, although it only assesses doses of up to 5 Gy (1).

\section{Absorbed dose and equivalent dose}

Absorbed dose presents the concentration of radiation energy that is absorbed at a specific point inside the tissue (4). Different tissues within the beam will absorb various doses, as a result of the attenuation of an x-ray beam when it passes the body (34). Tissues near the entrance surface will for that reason, have higher $\mathrm{AD}(8)$. Absorbed dose is defined as the quantity of radiation energy that is absorbed per unit mass of tissue". The SI unit is the Gray $(4,8)$. For diagnostic imaging, milligray is used $(1,4)$. AD shows estimated risk of radiation exposure in a particular tissue (4).

Equivalent dose is actually the absorbed dose that is adapted for the attenuation characteristics of the radiation (8). In order to calculate the equivalent dose, we need to multiply AD and a radiation-weighting factor (wR), which implies relative biologic effectiveness of the radiation. For a particle radiation, $w \mathrm{R}$ is 20 , and at the same time, the $\mathrm{wR}$ for X-rays is 1 (35). It is important to say, that it can be perplexing, but also opportune to have identical values for $\mathrm{AD}$ and equivalent dose (34). Equivalent dose is expressed in Sieverts, with milliSievert being more used in diagnostics $(4,34)$.

\section{Effective dose}

The radiation dose parameter that is associated with the risk of stochastic effects is called effective dose (4). ICRP advises the use of ED for the sake of evaluation of radiation exposure risk. Effective dose is reported in Sieverts (milli or micro Sieverts). On account of progress of the estimation of the stochastic effects risk, the ICRP has changed the calculation of ED several times (35). The most recent change was in 2007 and it was remarkable, for the reason that weights of several tissues were changed $(35,36)$. The effective dose is defined by ICRP as "the weighted sum of the mean doses to a number of radiosensitive tissues or organs in the body" $(35,37)$.

It is necessary to keep in mind that ED cannot be utilized to assess individual risk of patients' radiation exposure, due to the use of average characteristics, such as age and gender $(1,36)$. Still, ED is used to present the relative risk $(35,38)$.

\section{APPROACHES TO DOSE MEASUREMENTS}

The gold standard for measurement of ED and calculation of ED are possible with the use of phantom and Monte Carlo simulation (39). When the virtual simulator of human body is not possessed, AK and DAP are used (35, 40). For the estimation of effective dose, ICRP data on mean absorbed dose to twelve specific organs, are needed, since direct quantification isn't possible. Phantoms can also replicate certain organs that are area of interest and Monte Carlo simulation can provide coefficients for specific organ (28). Due to the fact, that this topic requires broad knowledge of radio physics, biophysics and radiology, it is necessary to increase the level of knowledge that radiologists have on radiation exposure and its measures (41). It is also necessary to obtain the radiation parameters and calculate or evaluate radiation doses during different types of interventional procedures, in order to improve awareness in medical teams who perform these procedures in everyday praxis $(42,43)$.

\section{CONCLUSION}

Advances in the field of interventional radiology, increased the number of procedures and patients that undergo them, which led to the greater exposure to radiation and potential stochastic and deterministic effects. These effects are not only hazardous for the patients, but for the medical team as well, in larger amount. Radiologist 
and medical stuff are often unconcerned about the radiation they are exposed, which can bring to harmful effects, especially in more complicated procedures. Optimization of radiation doses, education about measurement and increase of skill and experience are key factors to overcome this issue.

\section{ABBREVIATIONS}

IR - interventional radiology

IRP - interventional radiology procedures

$\mathrm{RD}$ - radiation dose

ICRP - International Commission on Radiological Protection

DAP - dose-area product

AK - air kerma

ESD - entrance-skin dose

ED - effective dose

AD - absorption dose

MSD - maximum skin dose

TESD - total entrance-skin dose

TLD - thermoluminescent dosimeter

wR - radiation-weighting factor

\section{REFERENCES}

1. Chida K, Kato M, Kagaya Y, et al. Radiation dose and radiation protection for patients and physicians during interventional procedure. J Radiat Res 2010; 51: 97105.

2. Tsapaki V, Ahmed NA, AlSuwaidi JS, et al. Radiation exposure to patients during interventional procedures in 20 countries: initial IAEA project results. AJR Am J Roentgenol 2009; 193: 559-69.

3. Walsh C, O'Callaghan A, Moore D, et al. Measurement and optimization of patient radiation doses in endovascular aneurysm repair. Eur J Vasc Endovasc Surg 2012; 43: 534-9.

4. Joiner M, van der Kogel A, eds. Basic clinical radiobiology. 4th ed. London: CRC Press, 2009.

5. Stecker MS, Balter S, Towbin RB, et al. SIR Safety and Health Committee; CIRSE Standards of Practice Committee. Guidelines for patient radiation dose management. J Vasc Interv Radiol 2009; 20: S263-73.

6. Boos J, Meineke A, Bethge OT, Antoch G, Kropil P. Dose monitoring in radiology departments: status quo and future perspectives. Rofo 2016; 188: 443-50.

7. Heidbuchel H, Wittkampf FH, Vano E, et al. Practical ways to reduce radiation dose for patients and staff during device implantations and electrophysiological procedures. Europace 2014; 16: 946-64.
8. Hall EJ, Giaccia AJ. Radiobiology for the radiologist. 6th ed. Philadelphia: Lippincott Williams \& Wilkins, 2006.

9. International Commission on Radiation Units and Measurements. Patient dosimetry for $\mathrm{x}$ rays used in medical imaging. J ICRU 2005; 5(2): iv-vi.

10. Vano E, Jarvinen H, Kosunen A, et al. Patient dose in interventional radiology: a European survey. Radiat Prot Dosimetry 2008; 129: 39-45.

11. Miller DL, Balter S, Cole P, et al. Radiation Doses in Interventional Radiology procedures: the RAD-IR Study: part II: skin dose. J Vasc Interv Radiol 2003; 14: 977-90.

12. Struelens L, Vanhavere F, Bosmans H, Van Loon R, Mol H. Skin dose measurement on patients for diagnostic and interventional neuroradiology: a multicentre study. Radiat Prot Dosimetry 2005; 114: 143-6.

13. Hirshfeld JW Jr, Balter S, Brinker JA, et al. ACCF/AHA/HRS/SCAI clinical competence statement on physician knowledge to optimize patient safety and image quality in fluoroscopically guided invasive cardiovascular procedures: a report of the American College of Cardiology Foundation/American Heart Association/American College of Physicians Task Force on Clinical Competence and Training. Circulation 2005; 111: 51132.

14. Moon EK, Wang W, Newman JS, Bayona-Molano Mdel P. Challenges in interventional radiology: the pregnant patient. Semin Intervent Radiol 2013; 30: 394-402.

15. Hidajat N, Wust P, Felix R, Schroder RJ. Radiation exposure to patient and staff in hepatic chemoembolization: risk estimation of cancer and deterministic effects. Cardiovasc Intervent Radiol 2006; 29:791-6.

16. Falter F, Screaton NJ. Imaging the ICU Patient. 1st ed. London: Springer-Verlag, 2014.

17. Chida K, Kagaya Y, Saito H, Ishibashi T, Takahashi S, Zuguchi M. Evaluation of patient radiation dose during cardiac interventional procedures: what is the most effective method? Acta Radiol 2009; 50: 474-81.

18. Chida K, Inaba Y, Masuyama H, et al. Evaluating the performance of a MOSFET dosimeter at diagnostic Xray energies for interventional radiology. Radiol Phys Technol 2009; 2: 58-61.

19. McParland BJ. Entrance skin dose estimates derived from dose-area product measurements in interventional radiological procedures. $\mathrm{Br} \mathrm{J}$ Radiol 1998; 71: 1288-95. 
20. Lazarus MS, Taragin BH, Malouf W, et al. Radiation dose monitoring in pediatric fluoroscopy: comparison of fluoroscopy time and dose-area product thresholds for identifying high-exposure cases. Pediatr Radiol 2019; 49: 600-8.

21. Balter S. Methods for measuring fluoroscopic skin dose. Pediatr Radiol 2006; 36: 136-40.

22. Stratis AI, Anthopoulos PL, Gavaliatsis IP, et al. Patient dose in cardiac radiology. Hellenic J Cardiol 2009; 50: 17-25.

23. Miller DL, Kwon D, Bonavia GH. Reference levels for patient radiation doses in interventional radiology: proposed initial values for U.S. practice. Radiology 2009; 253: 753-64.

24. Neil S, Padgham C, Martin CJ. A study of the relationship between peak skin dose and cumulative air kerma in interventional neuroradiology and cardiology. J Radiol Prot 2010; 30: 659-72.

25. Walsh SR, Cousins C, Tang TY, Gaunt ME, Boyle JR. Ionizing radiation in endovascular interventions. J Endovasc Ther. 2008 Dec;15(6):680-7.

26. Vano E, Gonzalez L, Ten J, Fernandez JM, Guibelalde E, Macaya C. Skin dose and dose-area product values for interventional cardiology procedures. Br J Radiol 2001; 74: 48-55.

27. Chida K, Saito H, Kagaya Y, et al. Indicators of the maximum radiation dose to the skin during percutaneous coronary intervention in different target vessels. Catheter Cardiovasc Interv 2006; 68: 236-41.

28. European Commission Directorate-General for Energy and Transport, Health Protection Agency Centre for Radiation Chemical and Environmental Hazards (Great Britain). European guidance on estimating population doses from medical $\mathrm{X}$-ray procedures. Luxembourg: Publications Office, 2008.

29. International Electrotechnical Commission. Medical electrical equipment: part 2-43-particular requirements for the safety of $\mathrm{x}$-ray equipment for interventional procedures. Report 60601-2-43. Geneva: International Electrotechnical Commission, 2000.

30. Fletcher DW, Miller DL, Balter S, Taylor MA. Comparison of four techniques to estimate radiation dose to skin during angio graphic and interventional radiology procedures. J Vasc Interv Radiol 2002; 13: 391-7.

31. Kuhelj D, Zdesar U, Jevtic V, et al. Risk of deterministic effects during endovascular aortic stent graft implantation. Br J Radiol 2010; 83: 958-63.

32. The 2007 Recommendations of the International Commission on Radiological Protection. ICRP publication 103. Ann ICRP 2007; 37: 1-332.
33. Ploussi A, Efstathopoulos EP. Importance of establishing radiation protection culture in Radiology Department. World J Radiol 2016; 8: 142-7.

34. Miller DL. Make radiation protection a habit. Tech Vasc Interv Radiol 2018; 21: 37-42.

35. Ludlow JB, Timothy R, Walker C, et al. Effective dose of dental CBCT-a meta analysis of published data and additional data for nine CBCT units. Dentomaxillofac Radiol 2015; 44: $20140197 . \quad$ (doi: 10.1259/dmfr.20140197).

36. Masjedi H, Zare MH, Keshavarz Siahpoush N, RazaviRatki SK, Alavi F, Shabani M. European trends in radiology: investigating factors affecting the number of examinations and the effective dose. Radiol Med 2020; 125: 296-305.

37. Stadnyk L, Shalopa O, Nosyk O. Collective effective dose from diagnostic radiology in Ukraine. Radiat Prot Dosimetry 2015; 165: 146-9.

38. Nekolla EA, Schegerer AA, Griebel J, Brix G. Frequency and doses of diagnostic and interventional $\mathrm{X} \square$ ray applications: trends between 2007 and 2014 . Radiologe 2017; 57: 555-62. (in German).

39. Thierry-Chef I, Simon SL, Land CE, Miller DL. Radiation dose to the brain and subsequent risk of developing brain tumors in pediatric patients undergoing interventional neuroradiology procedures. Radiat Res 2008; 170: 553-65.

40. Schmitz D, Vogl T, Nour-Eldin NA, et al. Patient radiation dose in percutaneous biliary interventions: recommendations for DRLs on the basis of a multicentre study. Eur Radiol 2019; 29: 3390-400.

41. Hankin RA, Jones SP. The impact of educational interventions on clinicians' knowledge of radiation protection: An integrative review. Radiography (Lond) 2020. pii: S1078-8174(20)30009-2. (doi: 10.1016/j.radi.2020.01.008).

42. Opancina V, Mijailovic M, Lukic S. Radiation exposure during interventional neuroradiology procedures. Proceedings of the Fifth International Conference on radiation and applications in various fields of research; 2017 Jun 12-16; Budva, Montenegro. Nis: RAD Association, 2017: 426. (Abstract book).

43. Opancina V, Lukic S, Mijailovic M. Evaluation of deterministic effects of radiation during interventional neuroradiology procedures. Proceedings of the 4th Serbian Congress of radiology with international participation; 2017 Nov 9-11; Zlatibor, Serbia. Belgrade: Serbian Society of Radiology, 2017. 